\title{
The evolution and practice of international administration on states and territories
}

\author{
MARKO AĆIĆ \\ PHD
}

Pan-European University Apeiron, Banja Luka e-mail: acicdominus@gmail.com

Keywords mandate system, the trusteeship system, protectorate, international organizations, the League of Nations, the United Nations, statutes, Bosnia and Herzegovina

Abstract Throughout the history of relations between states, it can be seen that various forms of supervision for weaker states or territories, whether external (by militarily and economically stronger individual states) or international (by intergovernmental organizations), have been established for periods of time in the form of protectorates, mandates, tutelage or temporary multinational administration. With the emergence and institutionalization of a new universal international organization, the League of Nations, the practice of external oversight and control of specific territories and states continued, but with a novel legal regime under its mandate system. The legal basis for the management of these territories through the authorization of the League of Nations and its successor, the United Nations, the rights and obligations of such countries as well as the most significant differences between the mandate, trusteeship and the protectorate arrangements, as the most representative example of international governance over certain countries and territories, will be analyzed in this paper. The comparative and content analysis methods will be used for this purpose, with special emphasis on the practical effects of international administration on the functioning of Bosnia and Herzegovina.

\section{Ewolucja i praktyka międzynarodowej administracji nad państwami i terytorium}

Słowa kluczowe system mandatowy, system powierniczy, protektorat, organizacje międzynarodowe, Liga Narodów Zjednoczonych, Organizacja Narodów Zjednoczonych, statuty, Bośnia i Hercegowina

Abstrakt

W historii stosunków międzynarodowych można zauważyć, że różne formy nadzoru nad słabszymi państwami lub terytoriami, zarówno zewnętrzne (przez państwa silniejsze pod względem militarnym i gospodarczym), jak i międzynarodowe (przez organizacje międzyrządowe), zostały ustanowione na pewien czas w formie protektoratów, mandatów, opieki lub tymczasowej administracji wielonarodowej.

Wraz z pojawieniem się i instytucjonalizacją nowej uniwersalnej organizacji międzynarodowej, Ligi Narodów, kontynuowano praktykę zewnętrznego nadzoru i kontroli określonych terytoriów i państw, ale z nowatorskim reżimem prawnym w ramach jej systemu mandatów. 


\begin{abstract}
Podstawa prawna zarządzania tymi terytoriami poprzez upoważnienie Ligi Narodów i jej następcy, Organizacji Narodów Zjednoczonych, prawa i obowiązki takich państw, jak również najbardziej znaczące różnice między mandatem, powiernictwem i ustaleniami protektoratu, jako najbardziej reprezentatywny przykład międzynarodowego zarządzania niektórymi państwami i terytoriami, przeanalizowano w niniejszym artykule.

W artykule wykorzystano metodę analizy treści i porównawczą, ze szczególnym uwzględnieniem praktycznych skutków administracji międzynarodowej dla funkcjonowania Bośni i Hercegowiny.
\end{abstract}

\title{
Introduction
}

Throughout history, and even today, by voluntary submission or by different forms of coercion, greater or lesser restrictions have been imposed on the sovereignty of individual states. This issue is often placed in the context of globalization itself and the changes it brings. In this field, these constraints have functioned via several models authorized by the League of Nations and the United Nations (UN). These will be briefly discussed by analyzing the major characteristics of the practice of protectorates, mandates and trusteeship arrangements. This resulting limitation of sovereignty illustrates the change in the "legitimacy of states in international relations over time" (Kelsen, 1966, p. 307-308). In this sense, one of the most obvious examples is precisely the establishment of an international administration system over territories which arises in situations where - for strategic, economic, military or political reasons - a given territory is placed under the administration of an international organization (hereinafter referred to as IO) or under the administration of (a) foreign state(s) (Debelez, 1967, p. 5).

With regard to the above arrangements, "international territorial administration, in addition to administrative restrictions on territorial sovereignty, therefore also provides protection of the vital interests of a particular group of states or of the international community as a whole" (Dimitrijević, 2010). These limitations of sovereignty, as a result of a specific allocation of rights to states and/or an IO, can be identified by their manifest forms, of which the most significant are the mandate, trusteeship, earlier versions of international protectorates, and specific administrations under the auspices of international organizations, as an example of contemporary practice.

\section{Classification of international systems of administration from a temporal aspect}

Without going into detailed elaboration of any of the above-mentioned limitations on the sovereignty of states by other states or an international organization, here it would suffice to lay out only the most significant instances and periods of their practice, in which countries have been placed under these different international legal regimes. Observed from the temporal aspect, we can divide all forms of international administration over territories into:

- the period after the First World War in which, as relevant examples, we can include international governance over a European city with specific status (Danzig/ Gdańsk in Poland), (Makowski, 1923, p. 109) or an area of strategic importance for the assured payment of war reparations, such as Saarland in Germany (Ćirković, 1935, p. 146) or 
Leticia in Colombia (Woosley, 1935, p. 94),

- also after the First World War, the international administration of certain former Ottoman provinces (Syria, Mesopotamia, Transjordan and Palestine), former German colonies in Africa (Togo, Cameroon, Namibia) and previously German-held territories elsewhere (Western Samoa, New Guinea, Nauru) assigned to various countries (United Kingdom, France, Belgium, South-Africa, Australia, New Zealand, Japan) in the form of League of Nations mandates (Britannica, 2009),

- the post-1945 trusteeship system for transitional arrangements for former colonies on the path to sovereign existence with UN support,

- another form of external supervision for post-conflict areas emerged in the second half of the 1990s, in the form of UN-led international administrations in Eastern Slavonia (United Nations Transitional Administration for Eastern Slavonia, Baranja and Western Sirmium, UNTAES), Bosnia and Herzegovina (United Nations Mission in Bosnia and Herzegovina, UNMBIH), East Timor (United Nations Transitional Administration in East Timor, UNTAET) and Kosovo-Metohija (United Nations Interim Administration Mission in Kosovo, UNMIK).

Even though some of the most important territories through history (even though there are plenty of criteria for the division of countries (Dimitrijević, 2010) $)^{1}$ ) and the practice of international administrations are briefly indicated above, due to the comprehensiveness and complex nature of the topic, the current overview intends to deal with a summary of the principal characteristics and distinctive features of the legal regimes applied to these territories.

\section{Mandate system}

In the period when the League of Nations operated, the most important legal status in the context of legal issues regarding the international administrations established by the Treaty of Versailles (Treaty of Versailles Arts. 100-108) was related to the territories controlled by the victorious states after the First World War. The basic documents that were the iustus titulus for the action of the newly-defined international administration were the statutes (Shaw, 2016, p. 287-308) adopted for each of these areas individually. It is important to note that these are specific documents of an international legal character, but which also contained elements of constitutional and administrative law, i.e., they also prescribed the system for exercising authority as well as part of the administrative rights and obligations. One of the special issues regulated by the aforementioned statutes was the determination of sovereignty principle that was separated and defined (Andrassy, Bakotić, Vukas, 1998, p. 107) from the future formal independence of the territory in the mandate system containing various instances of limitations to the benefit of the state that was the holder of the administration through the mandate system.

\footnotetext{
1 According to Professor D. Dimitrijević, during the period the League of Nations operated, and within the mandate system, we can distinguish three groups of countries: A - Mesopotamia-Iraq, Palestine with Trans-Jordan, Syria and Lebanon, B - Togo and Cameroon, German East Africa, V - Southwest Africa, the Island of Samoa, Nauru and New Guinea.
} 
Under this legal status, with certain modifications inherent in each mandatory territory, this was the case particularly in the Saarland area until 1935 (Ćirković, 1935, p. 47). Then, it again came under German sovereignty following a plebiscite, which is one of the most important institutions of direct democracy. Within this system of international administration, under the auspices of the League of Nations, we can also find the disputed Colombian city of Leticia (Woosley, 1935, p. 94-99) assigned to the authority of the League of Nations Dispute Resolution Commission for one year starting from 1933, together with the Lithuanian Memel (Klaipeda) region in 1924 (Blocizewski, 1923, p. 142-143).

In addition to the system of international governance mentioned above, a special legal regime was introduced after the First World War for the colonies and overseas territories in the possession of or administered by the defeated countries outside Europe. "As the peace treaties did not regulate the fate of the colonial areas of the defeated countries, through the provision of Article 22 of the Covenant of the League of Nations, a new political and legal concept on the system of colonial mandates was formulated, which implied control of the territorial administration of the mandate territories by the League of Nations" (Popović, 1930, p. 198-199) in order to "satisfy the interests of the victorious countries and the interests of the local population" (Ress, 1927, p. 145). In order to summarize the shorter elaboration of the mandate system, we consider it necessary to note that in essence it did not specify to whom the sovereignty of territory under the mandate system belonged. It was not possible to establish a clear distinction between the mandate and the protectorate, which led to opposing views on the legal status of these areas (Novaković, 1936, p. 256-259).

The essential difference between the protectorate and the mandate arrangement (Andrassy, Bakotić, Vukas, 1998, p. 105-115) is in the purpose of a mandate, which implied the ultimate intended achievement of complete independence for the territory by means of that system. It meant that the mandate had to be exercised by the administrative authority essentially in the interest of the local population. In comparison, the protectorate and the consequences of its exercise did not always necessarily take into account the interests of the local population. On the contrary, the practice of control as protectorate often resulted in the large-scale exploitation of the territory's natural resources and, frequently, led to significant violations of local populations' various individual and collective rights, which were later determined under the generic name of human rights and freedoms in legally binding international instruments.

\section{Trusteeship System}

Following the demise of the League of Nations, a "successor" to the previous mandate model for the administration of territories, the trusteeship system, was devised. It came into being with the adoption of the founding document for the post-war multilateral order in international law. The new international blueprint for collectively-authorized custodian responsibility, as regulated in Chapter XII of the UN Charter, constituted a transitional regime in the decolonization process, in order to provide the structure for the proclaimed aim of "conferring trusteeship of peoples from former colonial possessions who are still unable to manage themselves under the particularly difficult circumstances of the modern world, to the developed nations, given that these newly liberated nations should apply the principle that the welfare and development of these nations represents the sacred mission of civilization" (Rakić, 2009, p. 84). 
Observing the legal continuity of conducting international administration over particular territories, we notice that after the Second World War, the mandate system was transformed into a "custodian system" defined by the institution of trusteeship. "The concept of a trusteeship system is modeled on the basis of a customary law system (the Anglo-Saxon system). This system is partly based on the institutional, legal and ideological settings of the mandate system of the League of Nations" (Perritt Jr., 2011, p. 5) Under the auspices of the UN, care of these territories was carried out in two ways:

- under Chapter XI of the UN Charter regulating the administration of non-self-governing territories, and

- on the basis of Chapter XII of the UN Charter covering issues under trusteeship territories.

The administration of non-self-governing territories established in the UN system was primarily guided by the organization's concern about those territories and countries that did not reach the relevant level of organization and self-government, and were under the direct authority of the great powers. Article 74 of the UN Charter explains that the policy towards non-self-governing territories must be based on the principle of good neighborly relations, and an interest in those territories. Accordingly, all members of the UN have accepted the obligation to contribute to their full economic, political and overall development.

It is important to point out that the system of these territories, previously described, was significantly reduced, especially after the adoption of UN General Assembly Resolution 1514, which solved colonial relations issues by declaring that all peoples of non-self-governing territories had the right to self-determination (UN Declaration on the Granting of Independence to Colonial Countries and Peoples, 1960).

In this context, it is also important to note the adoption of another resolution by the same body, namely the Declaration on Principles of International Law concerning Friendly Relations and Co-operation among States, in accordance with the UN Charter (Declaration on Principles of International Law concerning Friendly Relations and Cooperation among States in accordance with the Charter of the UN, 1970). It established that the status of non-self-governing territories is separate and distinct from the territory of the administering state, which may last until the exercise of the right to self-determination in accordance with the UN Charter (Dimitrijević, 2010) as found in several judgments of the International Court of Justice (Western Sahara and other relevant cases) (ICJ Reports, 1975, p. 12-28, ICJ Reports, 1988, p. 275.).

Analyzing Articles 76 and 80 of the UN Charter, we can conclude that the basic levers on which the trusteeship system rests are in some way related to the goals of the UN itself, namely the preservation of international peace and security, and in addition, the achievement of overall progress for the territories and the preservation of their populations' rights.

The Charter itself established the Trusteeship Council (Kreća, 2012)2 as a separate organ in charge of all countries and territories to be kept under temporary custodian supervision. On

\footnotetext{
2 According to Professor M. Kreća, the Trusteeship Council had a special tripartite composition: "Members of the organization administering territories under trusteeship, permanent members of the UN Security Council who did not administer territories under trusteeship, and remaining members of the UN, elected by the UN General Assembly for a term of three years, so that the total number of Trusteeship Council members was equally divided between administering and non-administering members of the organization, which implies that they were political representatives, and not independent experts. The decisions were made by the majority of the members who were present."
} 
the basis of Chapter VIII of the UN Charter, the Trusteeship Council was entitled to "examine reports submitted by the administrative authority, receive and investigate petitions consulting with administrative authority, perform temporary tours of the territory under trusteeship at a time agreed with the administrative authority" (Avramov, Kreća, 2003, p. 555) to establish (permanent and temporary) committees and also to undertake other actions in accordance with trusteeship agreements. Analyzing the legal nature of trusteeship agreements, we can conclude with certainty that the agreements were often determined to favor third parties, where the beneficiary territories are just territories under trusteeship. The trusteeship system was terminated in 1994 with UN Security Council Resolution 956 (UN SC Res. No. 956, 1994), ending this legal regime over the Republic of Palau, which gained all the attributes of sovereignty and independence.

In summary, we can say that the entire trusteeship system had the goal of empowering non-selfgoverning territories to help them become independent states. "The final goal of the trusteeship system, as well as every individual case of trusteeship, is the final independence and autonomy of the given territory, and it comes to the state through 'its gradual evolution' that will be encouraged by the trustee and the UN to achieve "the ability to manage their affairs"' (Rakić, 2009, p. 86) in accordance with Article 76 of the UN Charter.

\section{Defining protectorates}

Aware of the fact that a paper of this volume cannot bring together all the elements related to the issue of protectorates in international law, we are emphasizing only the most important characteristics here. The simplest definition that can be found in the dictionaries of international law (Ibler, 1987, p. 259) defines the protectorate as the real dependence of a state on a stronger one, whether it is based on economic, military and/or political power. The established relationship between the protector state and the state in the vassal relationship was most often defined by an international treaty.

The history of international relations records a number of protectorates: "The protectorate of three great powers, England, France and Russia, in Greece, which lasted from 1832-1923, the Russian Protectorate in the Danubian Principalities from 1829 to 1856 and the Russian Protectorate in the Principality of Bulgaria 1878-1885" (Čamo, 2016). Several examples of protectorates in the $20^{\text {th }}$ century that lasted until after the Second World War may be cited as territories under "protection" (supervision and control over their various state functions carried out most often by European states) in the cases of Kenya, Southern Nigeria, Swaziland, North Rhodesia, Gambia, Zanzibar, Uganda, Brunei, Maldives, Kuwait and Oman. "The protectorate is generally based on an international treaty that regulates the rights and duties of both parties" (Ibler, 1987, p. 259).

In order to give examples for the legal definition we are analyzing, we will look at several types of protectorates. "According to international law, a region or country under a protectorate is a region under the diplomatic or military protection of stronger states. This form of government allows the state to accept fewer obligations, depending on the region's relationship with the stronger state. Nevertheless, the region under the protectorate functions with sovereignty and has it a government that also respects international law." (Pierre, Peters, 2000, p. 163-193). 
In addition, "relations in the protectorate imply that the state protector normally takes control of the foreign relations of this protectorate state as well as the affairs of its defense. Often the state protector has certain control over the affairs of the protectorate state" (Esthus, 1966) regardless of the actual exercise and policy of protectorate administration (Živković, 1999).

In addition to the summary above, our subject of analysis is also the modification of the administration over the territories that have, over the course of recent history, been transferred to international organizations (IOs). The transfer of administration has contributed by increasing the number of subjects of international law, their institutional strengthening and the role that IOs have played in stopping and preventing the return of conflicts. In the case of the functioning of Bosnia and Herzegovina (BiH), founded on the Dayton Peace Agreement (DPA), we will also try to show how international organizations acted in $\mathrm{BiH}$ in that period and later.

\section{The administration by the United Nations over states and territories today}

The last, and for us perhaps the most important stage in the subject of our discussion, is the IO administration over certain territories or "sovereign states" today. International administration over particular areas or, occasionally, with respect to entire states, draws its legal basis from Chapters VI and VII of the UN Charter, which contain norms related to diplomatic and preventive activities, ensuring, implementing and maintaining peace.

Generally speaking, this is primarily a case of "the relationship between the UN and a certain state" (Wolfrum, 1995, p. 1395-1398) that acts to preserve peace, and indirectly we find the link "with the principle of peaceful resolution of disputes in relation to violent means that the Charter prohibits" (Wilde, 2001, p. 523).

These administrations were set up in Trieste, Palestine, Cambodia, Somalia, Bosnia and Herzegovina, Eastern Slavonia, Baranja and Western Sirmium, Kosovo and Metohija. It is important to note that all these international administrations were based on the relevant resolutions of UN organs and lasted over shorter or longer periods of time.

\section{Bosnia and Herzegovina: protectorate or not?}

These IO mandates were exercised primarily by the UN (New Balkan Politics Journal, 2009) ${ }^{3}$ and NATO which, "through the establishment of territorial administration, carried out measures for securing peace and the consolidation of political, legal and economic status" (Dimitrijević, 2008, p. 116), but also frequently abused their mandate and violated the principles of international law (Aćić,2017, p. 272-463), for instance, in the case of Bosnia and Herzegovina. The conse-

\footnotetext{
3 "The main dilemma for some authors is whether the UN represents an international government or an inter-national organization. As we will see in the following explanation, the UN has some functions of international government, specifically, administration in post-conflict situations. The UN remains an international organization because, according to profs. Morgenthau and Thompson, neither an international government nor supranational government is yet to exist in the world. Our world is still a world of sovereign states, although with some exceptions, such as the European Union". B. Reka, UNMIK as an international governance within post-conflict society.
} 
quences of such international administrations in Bosnia and Herzegovina - installed to implement the Dayton Peace Agreement (hereinafter DPA) as a specific form of collective protectorate and carried out primarily through the exercise of the powers of international organizations present in the country, will be analyzed later in this paper.

As a state established by the DPA, Bosnia and Herzegovina, with its present constitutional order, is one of the most obvious examples of international administration over certain territories following the fall of the Berlin Wall. In the context of this issue, the specific form of international administration bears the characteristics of the defined term of protectorate. In this respect, a clear distinction should be made between the implementation of classic protectorates by one or several states and the exercise of authority by a universal intergovernmental organization (in which the dominant role in decision-making is played by its member states).

Both the military and civilian components of governance in Bosnia and Herzegovina, especially in the first years after the war, were completely dependent on the representatives of IOs, which had a crucial role in the formation of the first authorities. This way, the dependence and functioning of Bosnia and Herzegovina on the activities of IOs in the implementation of the DPA can be considered as the decisive difference between the international territorial administration under the mandate of an IO and the specific form of the protectorate currently practiced in Bosnia and Herzegovina. It is precisely this governance which is practiced in Bosnia and Herzegovina, especially during the first post-war years, but through a specific form referring to the appointment of a powerful international official (the High Representative) by the United Nations with a clear mandate and authority included in the DPA (Article II, Annex 10 of the Dayton Peace Agreement) exercising his broad competences to supervise the direction of domestic and foreign policy of the newly-formed state through a specific form of international administration bearing the hallmarks of a "UN protectorate".

The practice of the various intergovernmental organizations (NATO, UN, EU, OSCE) in Bosnia and Herzegovina in exercising their mandate after the DPA was in the spirit of this position since, after signing the DPA, the Bosnia and Herzegovina authorities were unable to function, but in most cases they were not even formed without decisive action carried out by the Office of the High Representative (OHR). All this points to the fact that "the institutional system established by the Dayton Peace Agreement (DPA) can be qualified as an indirect model of the UN Territorial Administration, because the OHR performs its tasks in accordance with certain resolutions of the UN, creating a multilayered system of international supervision under which an internationally authorized representative performs executive functions on behalf of the international community" (Stahn, 2001). At this point, we should emphasize the word "specific" form of protectorate, because this form of international administration, and above all, by the United Nations, does not have all the elements of the definition of protectors defined in international legal theory and practice. The classical protectorate rests on the legal relationship between the protector state and the state under the protection of that state or another group of states, where there is a waiver of certain sovereign rights. This kind of relationship is usually defined by an international treaty, which certainly, at least formally, is not the case in Bosnia and Herzegovina. Illegal transfers of powers (against the DPA) from entity to the state level as well as numerous breaches of human rights were caused by the acts of international organizations in Bosnia and Herzegovina. 
On the other hand, we will try to prove the degree of dependence of Bosnia and Herzegovina on international organizations precisely when it comes to the functionality of the authorities envisaged by the DPA, as well as through specific examples of abuse of the authority of the High Representative through which the DPA itself changes through the classic system of international administration. Chandler confirms that the international community has taken full control over the legislative and executive power in the state of Bosnia and Herzegovina, which was at least formally independent. We can also give Chandler's view that "while the international armies of observers, peacekeepers and administrative staff (international administrations) are becoming increasingly needed for Balkan stability, there is also less and less a role for the local population in deciding on their own future" (Chandler, 2000). It is necessary to point out that a large number of authors justify all the activities of the IOs and OHR in Bosnia and Herzegovina. For example, Bennet (Dizdarević, 2005, p. 37-41), Komšić, Meron and others jointly conclude that the representatives of all the IOs and OHR carried out all their activities from the DPA and they all had one goal, the normal functioning of Bosnia and Herzegovina (ECHR, LE 3.3.R. No. 3657/04, p. 2). Therefore, we encounter a particularly specific form of international administration ("UN protectorate") in Bosnia and Herzegovina. "In this state the Provisional Administration of International Organizations with the important attributes of the authorities" was established by the Dayton (Paris) Peace Agreement, which is conducted through regional organizations" (Milisavljević, 2007, p. 176-177). Several journalists from Die Tageszeitung (Die Tageszeitung, 2014) ${ }^{4}$, Deutsche Welle (Deutsche Welle, 2014) and from European news outlets shared the views expressed in The Guardian:

In a scathing critique of seven years of western efforts to turn Bosnia into a liberal democracy following the 1992-95 war, the study singles out the former Liberal Democrat leader Paddy Ashdown, whom it accuses of turning Bosnia into a "European Raj", deploying the methods and lessons of the British in India in the 19th century [...]. On average, Lord Ashdown was imposing 14 decrees or decisions every month, compared with an average of four in 1999 [...]. The central criticism of the international regime in Bosnia is that there are no checks and balances on Lord Ashdown's powers and no accountability, whether locally or internationally (Taynor, 2003).

In Bosnia and Herzegovina, where IOs have no formal accountability and a specific form of international administration continued for 20 years after the signing of the DPA, Professor Snežana Savić states that "it is not formalized anywhere, there is no mention of the existence of a protectorate in $\mathrm{BiH}$, there is no doubt that through its activities this one dimension (without accountability) is practically maintained" (Savić, 2011, p. 22).

\footnotetext{
4 According to Die Tageszeitung, in an article with the headline "The EU is failing in its protectorate", Bosnia is further from Europe than ever before, and the necessary political and economic reforms are not progressing. Bosnian reality is sad: there are more civil servants per inhabitant than in any other country. The administration is corrupt and at best rudimentary. Following these conclusions, views on the work of the High Representative have also been given by authors of Bosniak legal thought. Thus, Emir Hadžikadunić states that "the time has come for an internal political agreement, a more functional and efficient $\mathrm{BiH}$, a state without an international protectorate, without an OHR".
} 
This view was also expressed by the Council of Europe. On 23 June 2004, the Parliamentary Assembly of the Council of Europe adopted Resolution 1384 concerning the strengthening of the democratic institutions of Bosnia and Herzegovina, which states, inter alia:

The scope of the OHR is such that, to all intents and purposes, it constitutes the supreme institution vested with power in Bosnia and Herzegovina. In this connection, the Assembly considers it irreconcilable with democratic principles that the OHR should be able to take enforceable decisions without being accountable for them or obliged to justify their validity and without there being a legal remedy (Aćić, 2017, p. 465).

In terms of the international governance in Bosnia and Herzegovina, authors conclude that "the events in Bosnia reveal an international community only vaguely embracing the political trusteeship concept... As a result, it had to gradually strengthen the powers of the trustee as stronger oversight of local institutions proved necessary to achieve the goals of the intervention... the task was to take away the sovereignty of local authorities" (Perritt, 2011, p. 10). Lenard Cohen and John R. Lampe give a similar argument and at the end of their comprehensive analysis conclude that "the acceptance of democracy in the Western Balkans will continue to remind us of the international protectorate" (Cohen, Lampe, 2011).

When discussing this problem, it should not be forgotten that there are opposing views (OHR 2009): Christopher Bennett, a senior official at the Office of the High Representative in $\mathrm{BiH}$, in a letter to the institutions of the Republika Srpska, stated, "The numerous resolutions of the UN Security Council adopted subsequently accepted the scope of the authority of the High Representative, as well as the specific use of these powers in accordance with Chapter VII of the UN Charter. His mandate was recognized by the European Court of Human Rights and the Constitutional Court of BiH" (OHR, 2009). Such claims are supported by Dizdarević, who quotes the holders of international governance in Bosnia and Herzegovina: "High Representatives Carl Bildt, Carlos Westendorp and Wolfgang Petritsch have made some useful moves from the point of view of normalizing the situation in the country. Unified license plates and unified travel documents have improved freedom of movement, a unified/single currency has facilitated trade and financial flows" (Dizdarević, 2005, p. 37). As the European Court of Human Rights explained, the position of the High Representative was established by an international agreement as part of the machinery for the return of peace to the countries of the former Yugoslavia; the High Representative derives his powers under international law, including legally binding decisions of the Security Council; the High Representative is not subject to the control of any single State; the High Representative is not a body of any State; nor do his activities include the responsibility of any State as a subject of international law (ECHR-LE3.3R. No. 36357/04, p. 2). In conclusion, we can say that the general public is aware that in previous legal analyses several arguments have been raised concerning the fact that in Bosnia and Herzegovina the High Representative of the international community, under a UN Security Council mandate, has carried out an "experiment" with the functioning state of Bosnia and Herzegovina. Although "it was normatively or formally established with its current constitutional structure in 1995, since its creation, the DPA, to this day, has never been precise because of the cooperation of the United Nations/NATO/EU in Bosnia and Herzegovina and the High Representative" (Aćić, 2017, p. 465). One example would 
be the existence of foreign judges in the Constitutional Court as well as the still-active so-called "Bonn Powers" in the hands of the High Representative.

\section{Conclusion}

Although it can be seen that at the core of the mandate and trusteeship system there was care for the interests of the local population, as well as for achieving the full scope of sovereignty and independence, in practice, this was often not the case. In principle, we must confirm that the legal basis for their administration was under the mandate of international organizations in the articles or decisions of the organs of the League of Nations and the United Nations. The very fact that the international organizations that authorized and indirectly exercised international administration had a larger monopoly of physical force with economic superiority often kept people and territories in an unjustifiably long status of administration.

Bosnia and Herzegovina today, as a project of the international community confirmed by the Dayton Peace Agreement, is an independent state. On the other hand, through the functioning of some of its most important bodies, such as the Constitutional Court of $\mathrm{BiH}$, we can notice significant help in the administration of their most important processes from the representatives of international organizations. With the presence of the OHR and the High Representative, who still has the opportunity to impose laws and oust the highest elected officials at state and entity levels, it is clear that we cannot say that the process of international administration has ended in Bosnia and Herzegovina, although it is taking place on a smaller scale than in the first postwar years.

\section{References}

Aćić, M. (2017). The role of International Organizations in the creation and functioning of Bosnia and Herzegovina established by the Dayton peace agreement. Doctoral dissertation. Belgrade.

Andrassy, J., Bakotić, B.,Vukas, B. (1998). Međunarodno prawo 1. Zagreb: Školska knjiga.

Avramov, S., Kreća, M. (2003). Međunarodno javno prawo. Beograd: Savremena administracija.

Blociszewski, J. (1923). La Décision de la Conférence des Ambassadeurs du 16 février 1923. Revue Générale de Droit International Public, 30, 142-143.

Camo, H. (2016). Protektorati, države ograničene samostalnosti. Retrieved from: https://hamdocamo.wordpress. com/2016/04/17/protektorati-drzave-ogranicene-samostalnosti-ii-dio (25.06.2018).

Chandler, D. (2000). The Bosnian protectorate, and the implication for Kosovo. London: Pluto Press. Retrieved from: http://www.newleftreview.org/static/assets/archive/pdf/NLR23107.pdf (29.10.2018).

Ćirković, S. (1935). Sarska oblast. Beograd: Arhiv za pravne i društvene nauke, Br. 47, 146.

Cohen, L.J., R. Lampe. Embracing Democracy in the Western Balkans: From Postconflict Struggles toward European Integration. Retrieved from: https://www.wilsoncenter.org/book/embracing-democracy-the-western-balkanspostconflict-struggles-toward-european-integration\#sthash.ua2WSnbg.dpuf (10.7.2018).

Debelez, L. (1967). Le concept d'internationalisation. Revue Générale de Droit International Public, 5 (71). 
Declaration on Principles of International Law Concerning Friendly Relations and Co-operation among States in accordance with the Charter of the United Nations, A/RES/25/2625, 24 October 1970. Retrieved from: http://www. un-documents.net/a25r2625.htm (27.10.2018).

Declaration on the Granting of Independence to Colonial Countries and Peoples, UN General Assembly Resolution 1514 (XV), A/RES/1514 (XV), 14 December 1960.

Die Tageszeitung. "The EU is failing in its protectorate". Retrieved from: https://www.dw.com/sr/poraz-eu-u-sopstvenom-protektoratu/a-17992677 (28.10.2018).

Dimitrijević, D. (2008). Međunarodno regulisanje teritorije države. Beograd: Institut za međunarodnu politiku i privredu.

Dimitrijević, D. Međunarodna uprava nad teritorijama. Retrieved from: http://www.doiserbia.nb.rs/ft.aspx?id=002585551002239D (18.11.2015).

Dizdarevic, S. (2005). Bosna i Hercegovina: Nedovršena drzava? In: Bosna i Hercegovina na putu ka modernoj državi? (37-41). Sarajevo: Perspektive i prepreke, Fondacija Henrik Bol.

Esthus, R.A. Protectorates and spheres of influence. In: Encyclopedia of the New American Nation. Retrieved from: https://www.americanforeignrelations.com/O-W/Protectorates-and-Spheres-of-Influence.html (20.11.2015).

European Court of Human Rights, Council of Europe. Dušan Berić and Others against Bosnia and Herzegovina, Strasbourg, ECHR-LE3.3 R. No. 36357/04, 2.

http://www.newbalcanpolitics.org.mk/item/ UNMIK- as- an -international- governance- within- Post-Conflict Society (19.11.2015).

https://hamdocamo.wordpress.com/2016/04/11/protektorati-drzave-ogranicene-samostalnosti (28.06.2018).

https://www.britannica.com/topic/mandate-League-of-Nations (19.11.2016).

Ibler, V. (1987). Rječnik međunarodnog javnog prava. Zagreb: Informator.

Kelsen, H. (1996). Principles of International Law, Holt, New York, Rinehart \& Wilson, 307-308.

Letter from the OHR to the President of the National Assembly of Republika Srpska, 30 September 2009. Comment on the adopted Conclusions of the Government of the Republika Srpska dated 24 September 2009 (text in the author's possession).

Makowski, J. (1923). La situation juridique du territoire de la ville libre de Dantzig. Revue Générale de Droit International Public, 50.

Milisavljević, B. (2007). Nove mirovne misije Organizacije Ujedinjenih nacija, Centar za publikacije Pravnog fakulteta Univerziteta u Beogradu. Beograd: Javno preduzeće Službeni Glasnik.

Novaković, M. (1936). Osnovi međunarodnog javnog prava. Beograd: Jugoslovensko udruženje za međunarodno pravo.

Perritt, Jr. H. (2011). Structures and standards for political trusteeship, LA, UCLA. Journal of International Law and Foreign Affairs, 5.

Pierre, J., Peters, B.G. (2000). Governance Politics and the State - Difference between autonomous region and protectorate. Palgrave.

Popović, Đ. (1930). Liga naroda. Beograd: Srpska književna zadruga.

Rakić, B. (2009). Ostvarivanje mira preko međunarodnog organizovanja i integrisanja država. Pravni fakultet Univerziteta u Beogradu. Beograd: Centar za izdavaštvo i informisanje.

Ress, v. D.F. (1927). Les mandates internationaux. Paris: Rousseau \& Cie.

Savić, S. (2011). Republika Srpska u dejtonskoj BiH, Komesgrafika, Banja Luka. Retrieved from: http://assembly.coe. $\mathrm{int} / \mathrm{nw} / \mathrm{xml} / \mathrm{XRef} / \mathrm{Xref}-\mathrm{XML} 2 \mathrm{HTML}-\mathrm{en} . \mathrm{asp}$ ?fileid=17232\&lang=en (9.07.2016).

Shaw, M. (2016). The League of Nations Mandate System and the Palestine Mandate: What Did and Does It Say about International Law and What Did and Does It Say about Palestine? Israel Law Review, 3 (49), 287-308.

Stahn, C. (2001). International Territorial Administration in the former Yugoslavia: Origins, developments and Challenges ahead, Max-Planck-Institut für ausländisches öffentliches Recht und Völkerrech. Retrieved from: www. zaoerv.de/61_2001/61_2001_1_b_107_176.pd (29.10.2018). 
Stahn, C. (2008). The Law and Practice of International Territorial Administration: Versailles to Iraq and Beyond. Cambridge: Cambridge University.

Traynor, I. (2003). Ashdown running Bosnia like a Raj. The Guardian. Retrieved from: http:/www.theguardian.com/ world/2003/jul/05/politics.foreignpolicy (9.07.2016).

UN (1994). Security Council resolution 956 (1994) on the termination of the status of Palau as a Trust Territory. Retrieved from: http://daccess-ods.un.org/TMP/2221481.05502129.html (19.11.2015).

Western Sahara Case (1975). ICJ Report, 12-28, Land and Maritime Boundaries between Cameroon and Nigeria, ICJ Report (1998), p. 275, Kasikili/Sedudu Island - Botswana vs. Namibia (1999) ICJ report, 1045.

Wilde, R. (2001). From Danzig to East Timor and Beyond: The Role of International Territorial Administration. American Journal of International Law, 3 (95), 583-606.

Wolfrum, R. (1995). Internationalization. In: R. Bernhardt (ed.) Encyclopedia of Public International Law. Vol. II (p. 1395-1398). Amsterdam.

Woosley, L.H. (1935). The Leticia Dispute between Colombia and Peru. American Journal of International Law, 1 (29), 94-99.

Živković, A. Building Peace in the Balkans - The protectorate, a way to dominate. Le Monde Diplomatique. Retrieved from: https://mondediplo.com/1999/07/04balk (29.10.2018). 